\title{
Evaluation of contrast media used in man for coronary arteriography
}

\author{
D. C. Banks, E. B. Raftery, and S. Oram \\ From the Cardiac Department, King's College Hospital, London S.E.5
}

The electrocardiographic changes induced by the injection of four contrast media into the right and left coronary arteries of man are described. Comparisons have been made between the different media, the techniques used, and the individual coronary artery injected. We conclude that Hypaque 85 is the medium of choice for coronary arteriography, that injection into the right coronary artery is more hazardous than injection into the left, and that as far as safety is concerned there is nothing to choose between the Sones' and fudkins' techniques.

The electrocardiographic changes that occur when contrast media are injected into the left coronary artery of dogs have been used to assess their toxicity (Banks, Raftery, and Oram, 1969). We now report the results of a similar analysis of the electrocardiographic changes in man.

\section{Material}

One hundred and eighteen investigations, using either the Sones' (Sones and Shirey, 1962) or Judkins' (Judkins, 1967) techniques were performed on 107 patients being considered for surgical treatment of their coronary arterial disease. All the electrocardiograms recorded during the injection of contrast media were analysed for changes in rate and the incidence of dysrhythmias. The changes in the ST complex which were measured previously in the dog and found to be inconclusive (Banks et al., 1969) were ignored.

The change in rate after injection was expressed as a percentage of the resting rate. All rates were measured in terms of RR interval to allow the exact paper speed to be ignored and to permit comparison to be made between different injections. The $R R$ interval between the first two complexes of each record gave the resting rate, and the maximum slowing was given by the longest $R R$ interval recorded after injection. If there was no lengthening of the interval, the shortest interval measured gave the maximum change in rate. Dysrhythmias and other abnormalities were noted as they occurred.

The findings were grouped and, using Student's ' $t$ ' test, comparison was made between the four media, the artery, and the technique. The four media were Hypaque 85, Triosil 75, Conray 480, and Urografin 76 , and the techniques were those of Sones (Sones and Shirey, 1962) and Judkins (1967).

Received 23 September 1969.

\section{Results}

The mean changes in heart rate induced by the four media are given in Table I. Though the number of injections of the different media varied considerably, there was a highly significant difference between the changes in rate produced by Hypaque 85 and the other media - Hypaque 85: Triosil 75, $\mathrm{p}<0.001$; Hypaque 85: Urografin 76, $\mathrm{p}<$ 0.001 ; and Hypaque 85: Conray 480, $p<$ 0.001 . Hypaque 85 also caused fewer and less dangerous abnormalities than the other media.

A similar analysis is given in Table 2 for the changes produced by injection into the right or left coronary artery. The differences in heart rate induced by the arterial injections are highly significant, right:left $\mathrm{p}<$ 0.005 . The incidence of complications is also very different in each artery.

The comparison of the Sones' and Judkins' techniques is shown in Table 3. The changes in heart rate are again highly significant, Judkins: Sones $\mathrm{p}<0.00 \mathrm{I}$, and there is considerable difference in the complications produced.

\section{Discussion}

The ideal medium for use in coronary arteriography would cause no change in heart rate and no other complications. It has been shown previously (Gensini and Di Giorgi, 1964) that the safest media are those that contain a large percentage of methylglucamine salts, and our work in dogs (Banks et al., 1969) confirmed this finding. In the present study it is interesting to note that the medium which appeared safest in the dog, Hypaque 
TABLE I Results of injection of contrast media into coronary arteries

\begin{tabular}{|c|c|c|c|c|c|}
\hline Media & $\begin{array}{l}\text { No. of } \\
\text { injections }\end{array}$ & $\begin{array}{l}\text { Mean change in } \\
\text { heart rate }(\%)\end{array}$ & $\begin{array}{l}\text { Standard } \\
\text { error }\end{array}$ & Complications & $\%$ complications \\
\hline Hypaque 85 & 278 & $76 \cdot 7$ & I. IO & Blood pressure fall in I & 0.4 \\
\hline Triosil 76 & 298 & $88 \cdot 3$ & $I \cdot I 4$ & $\begin{array}{l}\text { Ventricular fibrillation in } 4 \\
\text { Asystole in } \mathrm{r} \\
\text { Left bundle-branch block in I } \\
\text { Cardiac infarction in I }\end{array}$ & $2 \cdot 3$ \\
\hline Urographin 76 & 89 & $90 \cdot 4$ & $3 \cdot 25$ & Complete heart block in I & $\mathbf{I} \cdot \mathbf{I}$ \\
\hline Conray 480 & 64 & $88 \cdot 9$ & $2 \cdot 13$ & $\begin{array}{l}\text { Ventricular fibrillation in I } \\
\text { Asystole in I }\end{array}$ & $3 \cdot I$ \\
\hline
\end{tabular}

85, caused more slowing in man than the other media but it caused far fewer other complications. A factor that may have accounted for this difference was that in the dog the iodine content of Hypaque and Triosil was kept constant whereas in patients the iodine content varied continuously as the amount of medium injected was that quantity required to opacify the arteries.

We believe that at present Hypaque 85 is the medium of choice. Urografin 76 causes less slowing than Hypaque 85, but in our experience the contrast produced is less satisfactory.

The difference in heart rate resulting from injection of the right and left coronary árteries, respectively, was considerable (Table 2). The left artery was associated with more slowing but fewer and far less serious complications. Slowing of heart rate after injection of contrast media into the coronary arteries has been reported by several authors (Gensini and Di Giorgi, 1964; Benchimol and McNally, I966; Ross and Friesinger, 1966). The mechanism of this slowing is obscure, but it closely resembles the effects of vagal stimulation and could be a direct effect of the media on the sinu-atrial node, or a reflex effect mediated via the myocardial receptors and the vagus nerve. If it resulted from a direct action on the sinu-atrial node, then more pronounced effects might be expected from injection into the right coronary artery which usually provides the blood supply to the node (James, I965), whereas our data indicate that more slowing is produced by injection into the left coronary artery. Three patients in this series were premedicated with atropine and given a general anaesthetic before the arteriogram was performed, and in all three the degree of slowing was less than the over-all mean. Injection into the right coronary artery in fact caused greater
TABLE 2 Comparison of results of injection into each coronary artery

\begin{tabular}{llllll}
\hline $\begin{array}{l}\text { Coronary } \\
\text { artery }\end{array}$ & $\begin{array}{l}\text { No. of } \\
\text { injections }\end{array}$ & $\begin{array}{l}\text { Mean change } \\
\text { in heart } \\
\text { rate }(\%)\end{array}$ & $\begin{array}{l}\text { Standard } \\
\text { error }\end{array}$ & Complications & $\begin{array}{l}\% \text { compli- } \\
\text { cations }\end{array}$ \\
\hline Right & 324 & $87 \cdot 1$ & $1 \cdot 18$ & $\begin{array}{l}\text { Ventricular fibrilla- } \\
\text { tion in 4 } \\
\text { Asystole in 2 } \\
\text { Complete heart block } \\
\text { in I } \\
\text { Fall in blood pressure } \\
\text { in I } \\
\text { Left bundle-branch } \\
\text { block in I }\end{array}$ \\
\hline Left & 485 & 82.7 & 0.92 & $\begin{array}{l}\text { Ventricular fibrilla- } \\
\text { tion in I }\end{array}$ & 0.2 \\
\hline
\end{tabular}

TABLE 3 Comparison of injecting of contrast media into the coronary arteries, using Sones' and fudkins' techniques

\begin{tabular}{llllll}
\hline Technique & $\begin{array}{c}\text { No. of } \\
\text { injections in heart } \\
\text { rate (\%) }\end{array}$ & $\begin{array}{c}\text { Mean change Standard } \\
\text { error }\end{array}$ & Complications & $\begin{array}{c}\% \text { compli- } \\
\text { cations }\end{array}$ \\
\hline $\begin{array}{c}\text { Judkins } \\
\text { (1967) }\end{array}$ & 376 & $81 \cdot 5$ & $1 \cdot 19$ & $\begin{array}{l}\text { Complete heart block } \\
\text { in I }\end{array}$ & 0.3 \\
\hline $\begin{array}{c}\text { Sones and } \\
\text { Shirley } \\
(1962)\end{array}$ & 405 & 87.5 & 0.92 & $\begin{array}{l}\text { Ventricular fibrilla- } \\
\text { tion in 5 } \\
\text { Asystole in 2 } \\
\text { Fall in blood pressure } \\
\text { in I } \\
\text { Left bundle-branch } \\
\text { block in I }\end{array}$ \\
\hline
\end{tabular}

slowing than into the left though the difference was not significant - right mean percentage slowing 88.3 per cent, left mean percentage slowing 90.8 per cent. The fact that the slowing produced when dye is injected into the left coronary artery is partially 
blocked by atropine or general anaesthesia suggests that the slowing is mediated via the vagus nerve.

The explanation of the much greater number of dysrhythmias produced by injection into the right coronary artery possibly depends on the fact that the blood supply to the atrioventricular node arises from the right artery in 90 per cent of subjects (James, 1965). If this region of the conducting system is interfered with, it might either depress conduction and lead to heart block or asystole, or induce a sudden burst of activity to cause various dysrhythmias ending with ventricular fibrillation.

The difference in change of heart rate and complications induced by the two techniques was considerable, but was probably not due to the techniques alone. As a result of our experiments in the dog (Banks et al., 1969), the medium used routinely was changed from Triosil 75 to Hypaque 85 at the same time as we adopted the Judkins' percutaneous method. Another variable was the increasing skill of the operator during the series, but this did not appear to be an important fac- tor as the complications were fairly evenly spaced over the time when we were using the Sones' technique which was for 62 per cent of the investigations.

We would like to thank Dr. R. Knill-Jones for his help with the statistical analysis.

\section{References}

Banks, D. C., Raftery, E. B., and Oram, S. (1969). Evaluation of contrast media used in coronary arteriography. British Heart fournal, 31, 645.

Benchimol, A., and McNally, E. M. (I966). Hemodynamic and electrocardiographic effects of selective coronary angiography in man. New England fournal of Medicine, 274, 1217.

Gensini, G. G., and Di Giorgi, S. (1964). Myocardial toxicity of contrast agents used in angiography. Radiology, 82, 24.

James, T. N. (1965). Anatomy of the coronary arteries in health and disease. Circulation, 32, 1020.

Judkins, M. P. (1967). Selective coronary arteriography. I. Percutaneous transfemoral technique. Radiology, 89, 815 .

Ross, R. S., and Friesinger, G. C. (1966). Coronary arteriography. American Heart fournal, 72, 437.

Sones, F. M. and Shirey, E. K. (I962). Cinecoronary arteriography. Modern Concepts of Cardiovascular Disease, 31, 735. 